\title{
Sexually transmitted viral infections in various population groups in Mogadishu, Somalia
}

\author{
H JAMA,*§ L GRILLNER, $\dagger$ G BIBERFELD, $\ddagger$ S OSMAN,§ A ISSE, \\ M ABDIRAHMAN, $\|$ S BYGDEMAN*
}

From the Departments of *Clinical Bacteriology, Huddinge University Hospital, $†$ Clinical Microbiology, Section of Virology, Karolinska Hospital, Karolinsk a Institute, and $\ddagger$ Immunology, National Bacteriological Laboratory, Stockholm, Sweden, and the Departments of $\$$ Morphology and Pathology and $\|$ Internal Medicine, Faculty of Medicine and Surgery, Somali National University, Mogadishu, Somalia

SUMMARY The prevalence of serum antibodies to human immunodeficiency virus (HIV), herpes simplex virus (HSV), and cytomegalovirus (CMV) and of hepatitis B virus (HBV) markers was investigated in different population groups, including prostitutes, in Mogadishu, Somalia.

Hepatitis B surface antigen (HBsAg) was detected in $37 \%$ of pregnant women, $4 \%$ of neonates, $22 \%$ of educated women, and $20 \%$ of prostitutes. No significant difference between the groups was observed for HBV. In contrast to figures reported from South East Asia, the prevalence of hepatitis $\mathrm{Be}$ antigen $(\mathrm{HBeAg})$ was $18 \%$ in prostitutes and only $3 \%$ in all other $\mathrm{HBsAg}$ positive subjects.

The prevalence of antibodies to HSV $(100 \%)$ and CMV $(90 \%)$ was very high, but antibodies against HIV were not detected in any of 471 sera. As the routes of transmission for HBV and HIV infections are considered to be similar, HIV will probably spread rapidly in Somalia once this virus has been introduced into the country.

Human immunodeficiency virus (HIV), earlier named LAV/HTLV-III, probably has an important role in Africa as causing a sexually transmitted disease (STD), but information is only available from a limited number of populations and countries. ${ }^{1}$ Other viral infections that have been associated with sexual transmission are hepatitis B (HBV), herpes simplex type 2 (HSV 2), cytomegalovirus (CMV), and human papillomavirus (HPV).

The prevalence of $\mathrm{HBV}$ infections in a society is proportional to the extent of the infectious reservoir and to the routes and possibilities of transmission. The prevalence of HBV carriers varies in different parts of the world and is much higher in developing countries $(5 \%$ to $20 \%)$ than in the developed world $(0 \cdot 1$ to $0.6 \%){ }^{2}$

CMV and HSV are ubiquitous, and HSV 2 causes an STD with an increasing impact in developed countries. The isolation of CMV from semen and cervical

Address for reprints: Mr Hinda Jama Ahmed, c/o Dr Lena Grillner, Department of Clinical Microbiology, Section of Virology, Karolinska Hospital, S-104 01 Stockholm, Sweden.

Accepted for publication 6 January 1987 secretions has pointed to the possibility of sexual transmission of this virus. ${ }^{3}$

Several studies have shown a high prevalence of antibodies to HIV in sera from inhabitants of some parts of Africa, such as Zaire, ${ }^{45}$ Uganda, ${ }^{6}$ Rwanda, ${ }^{7}$ and Kenya. ${ }^{8}$ The main route of transmission between people in Africa has been shown to be by heterosexual intercourse, and the ratio of men to women infected is close to $1: 1.4910$

Infectious diseases constitute a public health problem in Somalia. STDs, however, receive lower priority than programmes to control other infectious diseases. The prevalence of infections with HIV, HBV, CMV, or HSV in Somalia has not been reported.

The aim of the present study was to investigate the prevalence of hepatitis B markers and antibodies to HIV, HSV, and CMV in various groups of women in Mogadishu, Somalia and, by including a group of prostitutes, to try to evaluate the role of these viruses as causes of STDs. A group of newborn babies was also included, and additional patient groups were included to study antibodies to HIV. The prevalence of infections with human papillomavirus (HPV) could not be investigated as no serological tests for this virus are available. 


\section{Patients and methods}

\section{STUDY POPULATION}

The population of Somalia is about 5.5 million people, half of whom are nomads and the rest comprise farmers, villagers, and city people. The capital city, Mogadishu, with a population of about 800000 , is situated in the south, on the coast of the Indian Ocean.

This study was carried out in Mogadishu, in July and August 1985 and January 1986. A total of 242 serum samples were collected from three different groups of women aged 14 to 48 . Venous samples were collected from 75 pregnant women attending the department of obstetrics and gynecology, Banadir Hospital, Mogadishu, between 8 am and 2 pm all days of the week, except Fridays, during the study period. The mean age of these women was 25 (range 16 to 38 ). Eighty two women $(66(81 \%)$ of whom had a higher education and included physicians, nurses, university students, and administrative staff) volunteered to participate in the study. The mean age in this group was 23 (range 15 to 40 ) and two of them were pregnant. Sera were collected from 85 professional prostitutes, mean age 23 (range 14 to 48 ). These women had recently been detained in a military camp for a special programme arranged by the government concerning behaviour and health improvement. In addition, cord blood samples were obtained from 43 of the newborn babies.

Questions were asked according to a standardised protocol. Details included age, marital status, occupation, number of pregnancies, history of hepatitis, whether circumcised, and number of clients and foreign sexual contacts of the prostitutes. Of the 55 prostitutes who answered this question, 10 had had foreign clients. These 55 women had a mean of 14 (range one to 105) sexual partners a week. The mean age and range for the pregnant women and educated women whose sera were examined for HBV was 25 (16 to 38 ) and 23 (15 to 40), respectively. All women were circumcised. Informed consent was obtained from the participants.

A further 186 sera were included in the study for HIV antibody testing; 33 from children six months to 10 years old attending the Banadir Hospital, three from men attending the STD clinic, 23 from male health care workers, and 127 from inpatients and outpatients (69 men, 58 women aged 15 to 60$)$ at the department of internal medicine of the General Hospital and at the Forlanini Hospital, a hospital for patients with tuberculosis. Hence, a total of 471 sera were analysed for antibodies to HIV.

Because of the difficulties in obtaining sufficient blood samples from pregnant women, educated women, and newborn babies, the number of sera
Table 1 Number of subjects tested for antibodies to human imunodeficiency virus (HIV), herpes simplex virus (HSV), hepatitis $B$ virus $(\mathrm{HBV})$, and cytomegalovirus (CMV)

\begin{tabular}{lllll}
\hline Groups & $H I V^{*}$ & $H S V$ & $H B V$ & $C M V$ \\
\hline Pregnant women & 75 & 56 & 52 & 56 \\
Newborn babies & 43 & 30 & 26 & 30 \\
Educated women & 82 & 57 & 55 & 57 \\
Female prostitutes & 85 & 85 & 85 & 85 \\
\hline
\end{tabular}

*An additional 186 patients were tested for antibodies to HIV.

tested in the different serological tests varied (table 1).

\section{METHODS}

The collected blood samples were cooled to $4^{\circ} \mathrm{C}$ and brought to the university laboratory on the same day. The sera were stored at $-20^{\circ} \mathrm{C}$ until transported to Stockholm in a cooling box. Each serum was divided into aliquots for the different tests on arrival at the National Bacteriological Laboratory (NBL) and then stored at $-20^{\circ} \mathrm{C}$. Tests for detecting HBV markers, CMV, and HSV were performed at the Department of Virology, Karolinska Hospital, and tests for antibodies to HIV were carried out at the NBL.

\section{Detecting $\mathrm{HBV}$ markers}

All sera were tested for hepatitis B surface antigen (HBsAg) by radioimmunoassay (AUSRIA II, Abbott Laboratories, North Chicago). All sera with more than 5000 counts per minute (cpm) were retested, and results for sera with $5000 \mathrm{cpm}$ or fewer were confirmed by a neutralisation test. ${ }^{11}$ Antibodies to $\mathrm{HBsAg}$ (anti-HBs) and to hepatitis B core antigen $(\mathrm{HBcAg})$ (anti-HBc) were measured by radioimmunoassay using Ausab and Corab (Abbott Laboratories). All sera positive for $\mathrm{HBsAg}$ were also tested for hepatitis $\mathrm{B}$ e antigen $(\mathrm{HBeAg})$ and antibodies to $\mathrm{HBeAg}$ (anti-HBe) by enzymeimmunoassay (Abbott Laboratories). The instructions of the manufacturers were followed in performing the tests and in calculating the results.

\section{Detecting antibodies to $H S V$ and $C M V$}

Antibodies to HSV and CMV were analysed by an enzyme linked immunosorbent assay (ELISA). CMV IgG antibodies were measured against a nuclear CMV antigen ${ }^{12}$ and HSV IgG antibodies against a solubilised membrane HSV 1 antigen that also cross reacted with type 2 antibodies. ${ }^{12}$

\section{Detecting antibodies to HIV}

Antibodies to HIV were analysed with two different test kits, both based on an ELISA; Vironostica AntiHTLV-III (Organon Teknika) and HTLV-III EIA (Abbott Laboratories). Western blot was used for confirmation as described previously. ${ }^{13}$ 
STATISTICAL ANALYSIS

Descriptive statistics and correlation analysis with the $\chi^{2}$ test were performed using the computer programme, Quest (University of Umeå, Sweden).

\section{Results}

Hepatitis B virus markers were found in as many as $84 \%$ to $89 \%$ of the women in the three groups (table 2 ) and in $73 \%$ of the neonates. Slightly more than half of the subject had antibodies to surface or core antigens (either in combination or one or the other alone), which was a sign of resolved past infection. A high proportion of the women were carriers of $\mathrm{HBV}$, as shown by the presence of HBsAg in $20 \%$ to $37 \%$ of the sera tested. In contrast, only one of the babies was $\mathrm{HBsAg}$ positive, as was his mother.

The pregnant women had the highest rate of HBsAg positivity, but the differences between the three groups were not significant. No difference in prevalence of HBV markers could be shown in women aged under 20 compared with those over 20 , and no age group showed a prevalence that differed significantly from that of other age groups. In this study we did not find that marital status, occupation, or number of pregnancies influenced the prevalence of hepatitis B markers.

Table 3 shows the prevalence of $\mathrm{HBeAg}$ and anti$\mathrm{HBe}$ in 49 subjects with $\mathrm{HBsAg}$. $\mathrm{HBeAg}$ was found in one $(8 \%)$ of 12 educated women with $\mathrm{HBsAg}$ and in three $(18 \%)$ of the $17 \mathrm{HBsAg}$ positive prostitutes. Anti-HBe positivity ranged from $29 \%$ to $100 \%$ of those with $\mathrm{HBsAg}$. Of the overall $49 \mathrm{HBsAg}$ positive subjects, 16 lacked $\mathrm{HBeAg}$ and anti-HBe markers.

Table 4 shows the prevalence of CMV and HSV IgG antibodies, which ranged from $90 \%$ to $99 \%$ for CMV, whereas all of each group of the study population had HSV IgG antibodies.

All 471 samples were negative for antibodies to HIV in both tests, though at the first run 24 of the sample showed a low grade positivity with the test from Abbott. When retested, however, they were all negative, a finding which was confirmed by western blot testing.
Table 3 Hepatitis e antigen ( $\mathrm{HBe} \mathrm{Ag}$ ) and antibody to $\mathrm{HBeAg}$ (anti-HBe) in 49 people with hepatitis $B$ surface antigen ( $\mathrm{HBs} \mathrm{Ag}$ ) from Mogadishu, Somalia

\begin{tabular}{|c|c|c|c|}
\hline \multirow[b]{2}{*}{ Groups } & \multirow[b]{2}{*}{ No } & \multicolumn{2}{|c|}{ No $(\%)$ positive for } \\
\hline & & $\overline{H B e A g}$ & Anti-HBe \\
\hline $\begin{array}{l}\text { Pregnant women } \\
\text { Newborn babies } \\
\text { Educated women } \\
\text { Female prostitutes }\end{array}$ & $\begin{array}{r}19 \\
1 \\
12 \\
17\end{array}$ & $\begin{array}{l}0 \\
0 \\
1(8) \\
3(18)\end{array}$ & $\begin{array}{c}13(68) \\
1(100) \\
10(83) \\
5(29)\end{array}$ \\
\hline
\end{tabular}

\section{Discussion}

The $23 \%$ (49/218) prevalence of HBsAg found in the study population is one of the highest in the world. The overall HBV infection rate was $85 \%(185 / 218)$, which is comparable with the results from neighbouring African countries. ${ }^{14-16}$ In Ethiopia 5\% of children aged under 15 and $12 \%$ of those who were older were found to be chronic carriers. ${ }^{14} \mathrm{~A}$ study from Kenya also showed that the prevalence of HBsAg in blood donors was $14 \%:^{15}$

How is HBV transmitted in this society? In a population where there is a high carrier rate, polygamy is prevalent, and there are large numbers of prostitutes, sexual contact could be thought to be one important mode of transmission of HBV. We did not, however, find an increased prevalence of HBV markers in prostitutes, and it is apparent that sexual transmission is not a major route. In contrast, $58 \%$ of the prostitutes had syphilis compared with only $3 \%$ of the pregnant women. ${ }^{17}$ It seems reasonable to assume that in this population $\mathrm{HBV}$ infections are mainly acquired before the age of 15 , as we found no differences between the prevalence in various age groups. This finding agrees with reports from the Gambia, ${ }^{19}$ south west Africa, ${ }^{20}$ and Ethiopia. ${ }^{14}$

Although a large proportion of the pregnant women carried $\mathrm{HBsAg}$, none were infectious as none had $\mathrm{HBeAg}$. In contrast, vertical transmission from $\mathrm{HBeAg}$ positive mothers occurs in $90 \%$ in South East Asia. $^{21}$ In Africa horizontal transmission is more likely to occur within the family and is favoured by

Table 2 Hepatitis B virus ( $H B V$ ) markers in four study groups in Mogadishu, Somalia

\begin{tabular}{|c|c|c|c|c|c|}
\hline \multirow[b]{2}{*}{ Groups } & \multirow[b]{2}{*}{ No } & \multicolumn{4}{|c|}{ No (\%) with HBV markers } \\
\hline & & $H B s A g$ & $A n t i-H B s$ & $A n t i-H B c$ & Total \\
\hline $\begin{array}{l}\text { Pregnant women } \\
\text { Newborn babies* } \\
\text { Educated women } \\
\text { Female prostitutes }\end{array}$ & $\begin{array}{l}52 \\
26 \\
55 \\
85\end{array}$ & $\begin{array}{c}19(37) \\
1(4) \\
12(22) \\
17(20)\end{array}$ & $\begin{array}{l}22(42) \\
12(46) \\
22(40) \\
45(53)\end{array}$ & $\begin{array}{l}3(6) \\
6(23) \\
12(22) \\
14(16)\end{array}$ & $\begin{array}{l}44(85) \\
19(73) \\
46(84) \\
76(89)\end{array}$ \\
\hline
\end{tabular}


Table 4 Antibodies to cytomegalovirus (CMV) and herpes simplex virus (HSV) IgG in four study groups from Mogadishu, Somalia

\begin{tabular}{llll}
\hline & & \multicolumn{2}{l}{ No (\%) positive for } \\
\cline { 3 - 4 } Groups & No & & \multicolumn{2}{c}{ CMVIgG } & HSV IgG \\
\hline Pregnant women & 56 & $55(99)$ & $56(100)$ \\
Newborn babies & 30 & $27(90)$ & $30(100)$ \\
Educated women & 57 & $55(97)$ & $57(100)$ \\
Female prostitutes & 85 & $83(98)$ & $85(100)$ \\
\hline
\end{tabular}

low socioeconomic conditions and certain cultural practices, such as circumcision and scarification. Further prospective investigations are required to assess the age at which HBV infection is acquired and the possible routes of transmission.

CMV and HSV occur throughout the world, and low socioecomonic conditions and overcrowding seem to favour their transmission. ${ }^{3}$ In this study the prevalence of antibodies to CMV $(97 \%, 220 / 228)$ and HSV $(100 \%)$ was higher than in a developed country like Sweden, which has a $70 \%$ prevalence of CMV. ${ }^{22}$ On the other hand, our results are comparable with the high prevalence found in a serological survey in Uganda and Tanzania. ${ }^{3}$

Although none of the population studied had antibodies against HIV, further investigations about HIV antibodies are important. As HIV constitutes a problem in a neighbouring country, Kenya, it is probably only a matter of time before this infection is also introduced into Somalia. As the routes of transmission for HBV and HIV infections are considered to be similar, we expect a rapid spread of HIV infection in Somalia once this virus has been introduced into the country (if this is not already the case). Continuous screening of inhibitants of Mogadishu and other cities in Somalia for HIV antibodies is therefore urgent and should include blood donors, risk groups such as prostitutes, and patients attending the STD clinic. This surveillance programme might be undertaken with the financial aid of international support organisations. To prevent the infection from becoming endemic, strong and effective preventive measures should be applied by the health authorities as early as possible. These measures should include the education of both public and health staff about the risk of acquiring HIV.

We thank Professor Abdi Ahmed Farah for his support, Dr Mohamed Warsame and the staff of the department of obstetrics and gynaecology, Banadir Hospital, Mogadishu, for their valuable help in collecting the specimens from pregnant women, and Mrs Gudrun Nyman for her excellent secretarial help.

This work was supported by grants from the Swedish Agency for Research Co-operation with Developing Countries (SAREC), Stockholm, Sweden, and the Somali
Academy for Science and Arts (SOMAC), Mogadishu, Somalia.

References

1 Biggar RJ. The AIDS problem in Africa. Lancet 1986;i:79-82.

2 World Health Organisation. Viral hepatitis type B. WHO Tech Rep Ser 1973;512:13-15.

3 Ho M. Cytomegalovirus, biology and infection. 1st ed. New York: Plenum Publishing Corporation, 1982:92-4.

4 Piot P, Quinn TC, Taelman H, et al. Acquired immunodeficiency syndrome in a heterosexual population in Zaire. Lancet 1984;ii:65-9.

5 Biggar RJ, Melbye M, Kestens L, et al. Seroepidemiology of HTLV-III antibodies in a remote population of eastern Zaire. Br Med J 1985;290:808-10.

6 Serwadda D, Mugerwa RD, Sewankambo NK, et al. Slim disease: a new disease in Uganda and its association with HTLV-III infection. Lancet 1985;ii:849-52.

7 Van de Perre P, Clumeck N, Carael M, et al. Female prostitutes: a risk group of infection with human T-cell lymphotropic virus type III. Lancet 1985;ii:524-7.

8 Kreiss JK, Koech D, Plummer FA, et al. AIDS virus infection in Nairobi prostitutes. Spread of the epidemic to East Africa. N Engl J Med 1986;314:414-8.

9 Van de Perre P, Rouvroy D, Lepage P, et al. Aquired immunodeficiency syndrome in Rwanda. Lancet 1984;ii:62-5.

10 Clumeck N, Sonnet J, Taelman H, et al. Acquired immunodeficiency syndrome in African patients. $N$ Engl J Med 1984;310:492-7.

11 Cameron $\mathrm{CH}$, Briggs $\mathrm{M}$. Confirmation of specificity by neutralisation in immunoradiometric assay for Hepatitis B surface antigen. J Virol Methods 1980;1:113-6.

12 Evaldson G, Blomberg I, Grillner L, Nord CE, Weintraub A. The role of immunoglobulins in amniotic fluid growth inhibition of Bacteriodes fragilis, herpes simplex, coxsackie B 5 and cytomegalovirus. Med Microbiol Immunol (Berl) 1983;172:155-60.

13 Biberfeld G, Böttiger B, Karlsson A, et al. HTLV-III infection in homosexuals and hemophiliacs in Sweden. Cancer Res 1985;45 suppl:4609-11.

14 Tsega E, Mengesha B, Hansson BG, Lindberg J, Nordenfeldt E. Hepatitis A, B and delta infection in Ethiopia: a serological survey with demographic data. Am J Epidemiol 1986;123: $344-51$.

15 Bowry TR, Shah MV. A pilot study of hepatitis B viral markers in volunteer blood donors in Kenya, East Africa. Vox Sang 1983;44:385-9.

16 Gebreselassie L. Prevalence of specific markers of viral hepatitis $\mathrm{A}$ and $\mathrm{B}$ among an Ethiopian population. Bull WHO 1983;61:991-6.

17 Jama H, Hederstedt B, Osman S, Omar K, Isse A, Bygdeman S. Syphilis in women of reproductive age in Mogadishu, Somalia: serological survey. Genitourin Med 1987;63:326-8.

18 Goudeau A, Yvonnet B, Lesage G, et al. Lack of anti-HBc IgM in neonates with $\mathrm{HBsAg}$ carrier mothers argues against transplacental transmission of hepatitis B virus infection. Lancet 1983;ii:1103-4.

19 Whittle HC, Bradley AK, McLauchlan K, Ajdukiewicz AB. Hepatitis B virus infection in two Gambian villages. Lancet 1983;i:1203-6.

20 Botha JF, Ritchie MJJ, Dusheiko GM, Mouton HWK. Hepatitis B virus carrier state in black children in Ovamboland: role of perinatal and horizontal infection. Lancet 1984;i:1210-2.

21 Beasley RP, Hwang L-Y, Lee GC-Y, et al. Prevention of perinatally transmitted hepatitis B virus infection with hepatitis B immune globulin and hepatitis B vaccine. Lancet 1983;ii: 1099-102.

22 Ahlfors K, Ivarsson S-A, Johnsson T, Svanberg L. Primary and secondary maternal cytomegalovirus infections and their relation to congenital infection. Acta Paediatr Scand 1982;71:109-13. 